\title{
Abundance and potency of Non-Symbiotic Nitrogen-Fixing Bacteria in Padang Sapu-sapu, Pejem Village, Bangka
}

\author{
(Kelimpahan dan Potensi Bakteri Penambat $\mathrm{N}_{2}$ \\ Non-Simbiotik di Padang Sapu-Sapu Dusun Pejem, Bangka) \\ Hermiati $^{\left.1^{*}\right)}$, Eddy Nurtjahya ${ }^{1}$, Irdika Mansur ${ }^{2}$ \\ ${ }^{1} J u r u s a n$ Biologi, Fakultas Pertanian, Perikanan dan Biologi, Universitas Bangka Belitung \\ Kampus Terpadu UBB Balun Ijuk, Kecamatan Merawang, Kabupaten Bangka, Provinsi Kepulauan Bangka Belitung 33172 \\ ${ }^{2}$ SEAMEO BIOTROP, Jl. Raya Tajur, RT.05/RW.05, Pakuan, Kecamatan Bogor Selatan, Kota Bogor, Jawa Barat 16134
}

\section{ABSTRACT}

Padang sapu-sapu soil is similar with post-tin mining soil in its white sand texture and poor nutrient. One factor causes the disturbed land in Bangka Belitung islands is tin mining activity. One method to rehabilitate marginal soil is by utilizing the potential nonsymbiotic $N_{2}$ fixing bacteria, which are able to fertilize the soil and is able to provide macro nutrient. This study aims to measure the abundance and potency of non-symbiotic $N_{2}$-fixing bacteria in padang sapu-sapu, Pejem Village, Bangka. The site selection is determined by purposive sampling method and interviews and the samples were collected randomly. Isolation used selective media Ashby 's Monitol Agar and Azospirillum media. Morphological characterization was conducted on isolates and a series selective test was carried out, i.e. hipersentivity test, hemolysis test, IAA phytohormone test and nitrogenase test. The study of the abundance population of non-symbiotic $N_{2}$-fixing bacteria of two different locations showed that the total bacterial population in padang sapusapu is very small compared to its lowland forest. Isolate Azotobacter sp. TH105(a) from the lowland forests is potential as natural fertilizer.

Padang sapu-sapu memiliki kemiripan dengan lahan pasca penambangan timah pada karakteristik berpasir putih dan miskin hara. Salah satu penyebab keadaan kritis di Pulau Bangka Belitung adalah penambangan timah. Salah satu cara untuk menangani lahan kritis adalah memanfaatkan bakteri penambat $\mathrm{N}_{2}$ non-simbiotik. Bakteri tersebut merupakan bakteri potensial untuk menyuburkan tanah dan menyediakan unsur hara makro. Penelitian ini bertujuan mendata kelimpahan dan potensi bakteri penambat $\mathrm{N}_{2}$ nonsimbiotik di lahan padang sapu-sapu, Dusun Pejem, Bangka. Lokasi penelitian dipilih dengan metode purposive sampling dan wawancara. Sampel tanah diambil dari padang sapu-sapu dan hutan dataran rendah Dusun Pejem, Bangka secara acak. Isolasi dilakukan menggunakan media selektif Ashby's Monitol Agar dan media Azospirillum. Isolat yang diperoleh dicatat karakter morfologi dan dilakukan serangkaian uji selektif yakni uji hipersentivitas, uji hemolisis, uji fitohormon IAA dan uji nitrogenase. Hasil penelitian kelimpahan populasi bakteri penambat $\mathrm{N}_{2}$ non-simbiotik dari dua lokasi yang berbeda menunjukkan bahwa jumlah populasi di padang sapu-sapu sangat sedikit dibandingkan di hutan dataran rendah. Isolat Azotobacter sp. TH105 (a) dari dataran rendah berpotensi digunakan sebagai pupuk hayati.

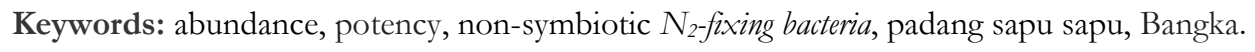

${ }^{*}$ )Corresponding author:

Hermiati

E-mail: hermiatisahid@gmail.com

\section{PENDAHULUAN}

Padang sapu-sapu merupakan vegetasi semak dengan pohon tertinggi hanya mencapai 5 meter [1]. Karakteristik tanah padang sapu-sapu yaitu berpasir putih dan miskin hara sehingga memiliki kesamaan dengan lahan pasca penambangan timah [1], [2]. Hutan padang sapu-sapu memiliki total $\mathrm{N}$ sebesar 0,07-0,41 [2] Menurut Patti et al. [3] kandungan N total tanah yang rendah berkisar 0,06-0,17 termasuk lahan kritis. 
Nitrogen $(\mathrm{N})$ adalah salah satu unsur hara makro yang penting yang ketersediaannya terbatas bagi tanaman, ketersediaan $\mathrm{N}$ di dalam tanah relatif lebih rendah $<2$ dibandingkan dengan kandungan $\mathrm{N}$ di udara sangat berlimpah yaitu sekitar $80 \%$ dari total gas di udara, $\mathrm{N}$ dapat dimanfaatkan oleh tanaman dengan bantuan bakteri penambat $\mathrm{N}_{2}(\mathrm{BPN})$, sehingga $\mathrm{N}$ dapat terikat kuat pada komponen tanah yang menyebabkan $\mathrm{N}$ tidak mudah terbilas keluar dari tanah dan dapat dimanfaatkan oleh tanaman [4].

Bakteri penambat $N_{2}$ non simbiotik memiliki kemampuan ganda yaitu sebagai agen penambatan N2 bebas di udara sekaligus sebagai pemantap agregat tanah. Menurut Miharja [5], bakteri penambat N2 non-simbiotik mampu menyuburkan tanah dan menyediakan unsur hara makro. Bakteri penambat N2 non-simbiotik merupakan salah satu agen hayati yang telah banyak dimanfaatkan dan diinformasikan sebagai pupuk hayati [6]. Setiadi [7] menyatakan bahwa salah satu bakteri yang berpotensi sebagai pupuk hayati yang dapat digunakan dalam proses revegetasi termasuk lahan krisis salah satunya yaitu bakteri penambat $N_{2}$ non simbiotik.

Lahan kritis Bangka Belitung diperkirakan mencapai \pm 428.561 ha. Salah satu lahan kritis tersebut adalah lahan pasca penambangan timah yang memiliki kemiripan dengan padang sapu-sapu. Upaya pemulihan lahan bekas tambang timah perlu dilakukan dengan pemanfaatan bakteri tanah yang potensial sebagai agen hayat seperti bakteri penambat $\mathrm{N}_{2}$.

Penelitian tentang bakteri penambat $\mathrm{N}_{2}$ di lahan kritis pernah dilakukan oleh Reyes et al. [8] yang berhasil mengisolasi bakteri Azotobacter sp. dari penambangan batuan fosfat. Widawati dan Muharam [9], melaporkan bahwa hampir seluruh isolat bakteri penambat $N_{2}$ non-simbiotik yang diisolasi dari tanah masam, terbukti sebagai penambat $\mathrm{N}_{2}$ bebas dari udara dan mampu meningkatkan kesuburan tanah dan menyediakan unsur hara makro serta mampu menghasilkan fitohormon indole acetic acid (IAA) dan gibberellic acid (GA).

Oleh sebab itu, perlu dilakukan penelitian mengenai kelimpahan dan potensi bakteri penambat $\mathrm{N}_{2}$ non-simbiotik di Padang Sapu-Sapu di Dusun Pejem, Bangka. Isolat bakteri potensial penambat $\mathrm{N}_{2}$ nonsimbiotik diharapkan mampu digunakan untuk pemulihan kesuburan tanah sebagai pupuk hayati di lahan kritis khususnya lahan pasca penambangan timah.

\section{METODE PENELITIAN}

Pada penelitian ini sampel tanah yang diambil berasal dari padang sapu-sapu dan hutan dataran rendah Dusun Pejem, Bangka.
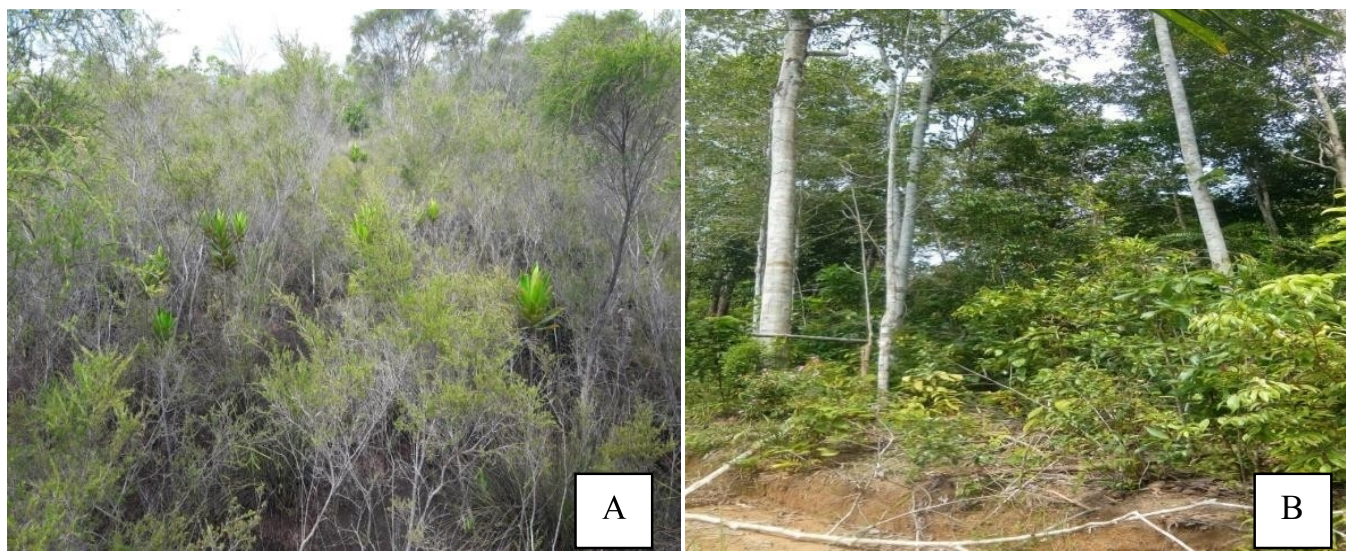

Gambar 1. Lokasi penelitian di padang sapu-sapu (A) dan hutan dataran rendah Dusun Pajem, Bangka (B)

\section{Teknik Pengambilan Sampel}

Penentuan titik lokasi pengambilan sampling berdasarkan purposive sampling dengan wawancara pribadi dengan Kepala Dusun Pejem. Analisis vegetasi dan analisis tanah mempergunakan data sekunder.

\section{Isolasi Bakteri Azotobacter}

Sebanyak $10 \mathrm{~g}$ sampel tanah dilarutkan ke dalam 90 $\mathrm{mL} \mathrm{NaCl}$ fisiologis $0,85 \%$, lalu dihomogenkan menggunakan shaker dengan kecepatan $120 \mathrm{rpm}$ selama 1 jam. Seri pengenceran dibuat $10^{-1}-10^{-7}$ dan sebanyak $1 \mathrm{ml}$ suspensi dari tiga pengenceran terakhir 
$\left(10^{-5}, 10^{-6}\right.$, dan $\left.10^{-7}\right)$ di inokulasi, pada media instan Himedia M706-500g Ashby's Monitol Agar yang merupakan media selektif bakteri Azotobacter sp. dilakukan dengan cara metode tuang [10]. Masingmasing dibuat 3 ulangan kemudian diinkubasi pada temperatur ruang $27-28^{\circ} \mathrm{C}$ selama 3-7 hari dengan posisi terbalik. Bentuk koloni bakteri Azotobacter sp dari media Ashby's Monitol Agar yaitu koloni kecil dan banyak, mengkilap, biasanya mempunyai permukaan yang datar dengan sedikit cekung di bagian tengah, seperti susu dan kelihatan bening [11]. Koloni bakteri yang didapat kemudian dilakukan pemurnian dengan cara digoreskan dengan metode streak plate pada media Ashby's Monitol Agar dan diinkubasi selama 24 jam pada temperatur ruang $28^{\circ} \mathrm{C}$.

\section{Isolasi Bakteri Azospirillum}

Sampel tanah $10 \mathrm{~g}$ dimasukkan ke dalam erlenmeyer yang berisi $90 \mathrm{ml}$ larutan $\mathrm{NaCl}$ steril dihomogenkan dengan vortex selama 60 menit. Suspensi tanah di encerkan hingga pengenceran $10^{-7}$. Pengenceran $10^{-5}, 10^{-6}$, dan $10^{-7}$ dipindahkan pada tabung reaksi yang berisi media instan Himedia Arospirillum semi-padat diinkubasi pada temperatur $37^{\circ} \mathrm{C}$ selama 72 jam. Pada media semi-padat Arospirillum tersebut akan terbentuk pelikel putih di bawah permukaan medium [12]. Pelikel putih dipindahkan lagi pada media baru Azospirillum semipadat selama 72 jam. Pemindahan dilakukan sebanyak tiga kali. Setelah dilakukan pemindahan selama tiga kali dan terbentuk pelikel lalu dipindahkan lagi pada media Arospirillum padat yang mengandung $20 \mathrm{Mg}$ ekstrak ragi per liter dan dipadatkan dengan agar 1,5\%. diinkubasi pada temperatur $37^{\circ} \mathrm{C}$ selama satu minggu [13]. Setelah bakteri didapat, dilakukan pemurnian dengan metode streak plate pada media Azospirillum agar dan diinkubasi selama satu minggu pada temperatur ruang $27-28^{\circ} \mathrm{C}$.

\section{Karakteristik Morfologi Bakteri Penambat $\mathbf{N}_{2}$ Non-Simbiotik}

Pengamatan morfologi koloni bakteri penambat $\mathrm{N}_{2}$ non-simbiotik menggunakan media Ashby ss Monitol Agar untuk bakteri Azotobacter sp dan media Azospirillum padat untuk bakteri Azospirillum dilihat dari warna koloni, tepi koloni, bentuk koloni, permukaan koloni, elevasi koloni, uji gram dan bentuk sel [14].

\section{Uji Hemolisis dan Uji Hipersensivitas}

Uji hemolisis mengunakan media Blood Agar secara langsung. Uji bakteri ini dilakukan dengan menginokulasikan satu ose isolat bakteri pada permukaan media Blood Agar, kemudian diinkubasi pada temperatur $37^{\circ} \mathrm{C}$ selama 18-24 jam. Pengamatan karakter hemolisis didasarkan atas bentuk zona hemolisis di sekeliling koloni bakteri Balashova et al. (2006) dalam Sari [15].

Uji hipersensitivitas isolat bakteri diinokulasikan ke media NB selama 2 hari. Suspensi bakteri kemudian disuntikkan pada sisi abasial daun daun tembakau. Pengamatan dilakukan setelah 48 jam dengan melihat gejala nekrotik pada daun tembakau Balashova et al. (2006) dalam Sari [15].

\section{Uji Fitohormon IAA}

Kultur bakteri ditumbuhkan pada media LB (Luria Bertani) selama 24 jam lalu diuji dengan cara ditetesi dengan larutan Salkowski. Hasil positif ditunjukkan dengan terjadinya perubahan warna menjadi merah muda setelah diinkubasi di tempat gelap selama 30 menit. Uji kualitatif dengan menggunakan metode kolorimetri dengan reagen Salkowski [16].

\section{Pengujian Aktivitas $\mathbf{N}_{2}$}

Pengukuran aktivitas nitrogenase dilakukan dengan metode Acetylene Reduction Assay (ARA) dengan alat kromatografi gas [17]. Pengukuran aktivitas nitrogenase menggunakan kultur bakteri berumur satu bulan namun kultur bakteri ditumbuhkan kembali pada media Ashby's Monitol Agar selama 72 jam lalu dilakukan uji aktivitas nitrogenase dan pengujian di Environmental Biotechnology Laboratory ICBB (EBLICBB) Bogor.

\section{HASIL DAN PEMBAHASAN}

Isolasi bakteri penambat $N_{2}$ non-simbiotik pada sampel tanah yang berasal dari hutan padang sapusapu dan hutan dataran rendah Dusun Pejem didapatkan sembilan isolat. Tiga isolat pada media Azospirillum dan enam isolat pada Ashby's Monitol Agar, yang memiliki karakter yang berbeda (Tabel 1).

Karakteristik isolat pada media Azospirillum yang berasal dari padang sapu-sapu memiliki morfologi koloni dengan bentuk bulat berukuran kecil 
dan sedang, dengan elevasi dominan cembung, memiliki margin rata dan tidak rata, dan seluruh isolat merupakan gram positif dengan bentuk sel basil dan isolat yang berasal dari hutan memiliki karakteristik bentuk koloni bulat, margin rata, ukuran sedang, dengan elevasi cembung bentuk sel cocus dan bergram positif. Karakteristik morfologi pada media Azospirilum disajikan pada tabel 1.

Isolat bakteri penambat $N_{2}$ non-simbiotik pada media Ashby's Monitol Agar yang berasal dari padang sapusapu memiliki karakteristik morfologi dengan warna koloni putih kuning, bentuk bulat, margin rata dan elevasi cembung. Bentuk sel cocus dan bertipe gram negatif. Isolat yang berasal dari hutan memiliki karakteristik morfologi koloni yang bentuknya dominan bulat dan satu isolat ireguler dengan elevasi dominan cembung, walaupun ada beberapa datar dan ukuran bervariasi ada yang kecil, sedang dan besar dengan margin dominan rata dan satu tidak rata dan warna, isolat yang bervariasi ada putih, putih susu, putih bening dan memiliki bentuk sel ada basil dan cocus, semua bertipe gram negatif karakteristik morfologi disajikan pada Tabel 1.

Berdasarkan hasil karakteristik morfologi dan fisiologi isolat bakteri pada media Azospirilum, bakteri yang tumbuh diduga memiliki kesamaan morfologi dengan bakteri Streptomyces dengan morfologi koloni berwarna putih, elevasi cembung, margin rata bentuk sel basil dan bergram positif [18].

Tumbuhnya bakteri Streptomyces pada media Azospirillum diduga $\mathrm{pH}$ pada media yang digunakan merupakan tempat tumbuhnya bakteri Streptomyces Arwiyanto et al. [19] menyatakan bahwa kisaran $\mathrm{pH}$ bakteri Streptomyces yaitu 4,3 sampai 8 dan kisaran temperatur $5^{\circ} \mathrm{C}$ sampai $45^{\circ} \mathrm{C}$.

Tabel 1. Karakter morfologi bakteri penambat $\mathrm{N}_{2}$ non-simbiotik (BPN) di Padang sapu-sapu dan hutan dataran rendah

\begin{tabular}{|c|c|c|c|c|c|c|c|}
\hline \multicolumn{8}{|c|}{ Karakter } \\
\hline $\begin{array}{l}\text { Kode } \\
\text { Isolat }\end{array}$ & Bentuk & Elevasi & Ukuran & Margin & Warna & $\begin{array}{c}\text { Bentuk } \\
\text { Sel }\end{array}$ & Uji gram \\
\hline \multicolumn{8}{|c|}{ Media Ashby' Monitol Agar } \\
\hline TH 105 (a) & bulat & Cembung & sedang & rata & putih susu & Cocus & - \\
\hline SH 106 (a) & bulat & Cembung & kecil & rata & putih & Basil & - \\
\hline TH 107 (b) & bulat & $\begin{array}{l}\text { Datar } \\
\text { datar }\end{array}$ & besar & ombak & putih bening & Cocus & - \\
\hline PH 105 & bulat & Cembung & sedang & rata & putih bening & Basil & - \\
\hline \multicolumn{8}{|c|}{ Media Azospirillum } \\
\hline ZPS 106 (a) & bulat & Cembung & kecil & rata & putih bening & Basil & + \\
\hline ZPS 107 (b) & bulat & Cembung & sedang & ombak & putih susu & Basil & + \\
\hline
\end{tabular}

Keterangan: TH (tiang hutan), SH (semai hutan), PH (pancang hutan) dan ZTH (tiang hutan) = isolat pada hutan, PS (pancang sapu-sapu), ZPS (padang sapu-sapu) = isolat padang sapu-sapu, TH, SH, PH dan PS= pertumbuhan isolat pada media Ashby `s Monitol Agar, ZPS dan ZPH = pertumbuhan isolat pada media Azospirillum PS 107(a), TH 105(a), SH 106(a) ZPS 106(a), dan ZTH 105(a)= isolat kedalaman 0-10, TH 105(b), TH 107(b), PH 105(b) dan ZPS 107(b)= isolat kedalaman 10-20

pH media yang digunakan pada penelitian yaitu 77,8 untuk media padat dan 6,8 untuk media semi padat. Sehingga pertumbuhan bakteri pada media Azospirillum adalah bakteri Streptomyces. Pertumbuhan bakteri Azospirillum dapat dipengaruhi oleh komposisi dari media tumbuh dan $\mathrm{pH}$. Rusmana dan Hadijaya [20] menyatakan bahwa pertumbuhan bakteri Arospirillum sangat baik pada medium yang mengandung asam malat, asam suksinat atau piruvat dan pertumbuhannya kurang baik pada glukosa dan asam sitrat. Astuti [21] menyatakan bahwa pertumbuhan bakteri Azospirillum perlu memperhatikan $\mathrm{pH}$ karena akan menghalangi pertumbuhan bakteri akibat tingginya $\mathrm{pH}$ media. Alexander [22] menyatakan bahwa Azospirillum hidup pada lingkungan dengan $\mathrm{pH}$ 6,8-7,9.

Pertumbuhan bakteri Azospirillum juga dipengaruhi oleh habitat lingkungan. Bakteri ini tumbuh baik pada $\mathrm{pH} 7$ dan tidak mampu hidup di $\mathrm{pH}$ asam, tanah yang mempunyai $\mathrm{pH}$ di bawah 5,7 
umumnya tidak mengandung Azospirillum. Holt et al. [13] menyatakan bahwa keberadaan bakteri Azospirillum bergantung dengan pH. Berdasarkan hasil analisis tanah hutan dataran rendah Pejem, $\mathrm{pH}$ tanah adalah 4,6 dan penelitian Nurtjahya et al. [2] menyatakan $\mathrm{pH}$ tanah padang sapu-sapu 4,1-5,1 atau asam sehingga tidak ditemukan bakteri Azospirillum.

Enam isolat bakteri pada media Ashby's Monitol Agar pada dua lokasi, terdapat satu isolat berasal dari padang sapu-sapu dan lima isolat ditemukan pada hutan dataran rendah. Koloni bakteri yang berasal dari padang sapu-sapu dengan kode isolat PS 107(a) memiliki karakteristik tidak berbeda jauh dangan isolat TH 105(a) dan PH 105(b) yang berasal dari hutan dataran rendah, namun memiliki perbedaan warna. Berdasarkan karakteristik pada media Ashby's monitol Agardi dua lokasi diduga memiliki kemiripan dengan bakteri penambat $\mathrm{N}_{2}$ non-simbiotik. Azotobacter. Pernyataan ini pun didukung oleh penelitian Isminarni et al. [23] yang menyatakan bahwa Azotobacter memiliki karakteristik koloni dengan bentuk bulat, cembung, warna koloni putih, bening, kuning sampai keruh dan coklat.
Karakter kunci utama genus Azotobacter adalah sel berbentuk cocus dan batang. Berdasarkan uji gram dan bentuk sel dari enam isolat ditemukan semua isolat bertipe gram negatif dengan bentuk sel bervariasi yaitu ada berbentuk basil dan cocus. Menurut Cowan et al. (1993), diacu dalam Kaburuan et al. [24] menyatakan genus Azotobacter termasuk ke dalam bakteri gram negatif, berbentuk batang dan cocus.

\section{Uji seleksi bakteri penambat $\mathrm{N}_{2}$ (BPN) non- simbiotik}

Isolat bakteri yang diperoleh dari media Azosprillum tidak diuji lebih lanjut karena tidak ditemukan ciri-ciri dari bakteri Azospirillum. Isolat yang diperoleh pada media Ashby's Manitol Agar menunjukkan mampu menghasilkan fitohormon IAA.

Uji hemolisis dan hipersentivitas dari enam isolat hanya satu isolat yang tidak menyebabkan reaksi hipersentivitas dan hemolisis yaitu isolat dengan kode TH105 (a). Isolat TH105(a) mampu mereduksi asetilen menjadi etilen sebesar $0,397 \mathrm{mg} / \mathrm{Kg}$ disajikan pada Tabel 2.

Tabel 2. Hasil uji seleksi bakteri Media Ashby' Monitol Agar

\begin{tabular}{ccccc}
\hline Kode isolat & $\begin{array}{c}\text { Uji } \\
\text { hipersentivitas }\end{array}$ & Uji hemolisis & $\begin{array}{c}\text { Uji } \\
\text { IAA }\end{array}$ & $\begin{array}{c}\text { Uji } \\
\text { aktivitas nitrogenase }\end{array}$ \\
\hline PS 107(a) & nekrosis & $\gamma$ & + & tidak dilakukan \\
TH 105(a) & nekrosis & $\gamma$ & + & tidak dilakukan \\
SH 106(a) & nekrosis & $\alpha$ & + & tidak dilakukan \\
TH 105(b) & tidak nekrosis & $\gamma$ & + & 0,379 \\
TH 107(b) & tidak nekrosis & $\alpha$ & + & tidak dilakukan \\
PH 105(b) & nekrosis & $\alpha$ & + & tidak dilakukan \\
\hline
\end{tabular}

Keterangan: $\gamma=$ gamma (tidak lisis), $\alpha=$ alfa (lisis setengah)

Hasil dari dua lokasi menunjukkan bahwa enam isolat mampu menghasilkan fitohormon IAA ditandai dengan terbentuknya warna merah muda. Namun dari enam isolat tersebut lima isolat diduga patogen dan dilihat dari uji hipersentivitas dan hemolisis. Isolat yang tidak berpotensi patogen yaitu isolat dengan kode TH 105(a). Hal ini menunjukkan bahwa isolat tersebut bisa dijadikan sebagai kandidat pupuk hayati atau biofertilizer. Kemampuan bakteri penambat $\mathrm{N}_{2}$ nonsimbiotik dalam menghasilkan hormon tumbuh indole acetic acid (IAA) sudah banyak diketahui khususnya bakteri Azotobacter. Gholami et al. [25] menyatakan bahwa Azotobacter merupakan bakteri fiksasi $\mathrm{N}_{2}$ yang mampu menghasilkan substansi zat pemacu tumbuh IAA.
Uji aktivitas nitrogenase dengan metode acetylene reduction assay (ARA) dilakukan untuk menguji kemampuan bakteri dalam menambat $\mathrm{N}_{2}$ yang diukur berdasarkan kemampuan enzim nitrogenase dalam mereduksi asetilen $\left(\mathrm{C}_{2} \mathrm{H}_{2}\right)$ menjadi etilen $\left(\mathrm{C}_{2} \mathrm{H}_{4}\right)$ [25]. Hasil uji aktivitas nitrogenase pada isolat TH105(a) menunjukkan bahwa isolat memiliki kemampuan dalam menambat $\mathrm{N}_{2}$ sebesar $0,379 \mathrm{mg} / \mathrm{Kg}$. Penelitian yang dilakukan oleh Firrani [26], kemampuan isolat bakteri yang diisolasi dari akar kelapa sawit dalam menambat nitrogen menghasilkan 3,13 $\mathrm{mg} / \mathrm{Kg}$. Kemampuan isolat bakteri TH105(a) dalam menambat $\mathrm{N}_{2}$ dapat dikatakan bahwa isolat tersebut merupakan bakteri penambat $\mathrm{N}_{2}$ non-simbiotik yang potensial. Kriteria bakteri penambat $\mathrm{N}_{2}$ non-simbiotik 
yaitu tidak patogen, menambat $\mathrm{N}_{2}$ dan menghasilkan fitohormon IAA.

Kelimpahan populasi bakteri penambat $\mathrm{N}_{2}$ nonsimbiotik dari dua lokasi yang berbeda menunjukkan bahwa jumlah populasi bakteri BPN non-simbiotik yang tertinggi yaitu di hutan dataran rendah dengan jumlah populasi sebesar $85,32 \times 10^{9}$ sedangkan di padang sapusapu jumlah populasi bakteri BPN non-simbiotik sebesar $0,33 \times 10^{9}$ (Tabel 3).

Tabel 3. Kelimpahan bakteri penambat $\mathrm{N}_{2}$ non-simbiotik (BPN) pada padang sapu-sapu dan hutan dataran rendah di Dusun Pejem, Bangka

\begin{tabular}{|c|c|c|c|c|c|c|}
\hline \multirow{2}{*}{ Lokasi } & \multirow{2}{*}{$\begin{array}{l}\text { Tingkat } \\
\text { pertumbuhan } \\
\text { pohon }\end{array}$} & \multirow{2}{*}{ Vegetasi Dominan } & \multicolumn{2}{|c|}{$\begin{array}{c}\text { Rata-rata jumlah BPN } \\
(\text { CFU g-1 tanah })\end{array}$} & \multirow{2}{*}{$\begin{array}{c}\text { Total } \\
\text { populasi } \\
\text { bakteri } \\
\left(\mathrm{CFU} \mathrm{g}{ }^{-1}\right. \\
\text { tanah) }\end{array}$} & \multirow{2}{*}{$\begin{array}{c}\text { Total populasi bakteri } \\
\text { dua lokasi }\end{array}$} \\
\hline & & & $0-10 \mathrm{~cm}$ & $10-20 \mathrm{~cm}$ & & \\
\hline \multirow{3}{*}{$\begin{array}{l}\text { Padang } \\
\text { sapu-sapu }\end{array}$} & semai & $\begin{array}{c}\text { sapu-sapu (Baeckea } \\
\text { frutescens) }\end{array}$ & - & - & - & \multirow{3}{*}{0,33} \\
\hline & pancang & $\begin{array}{c}\text { sapu-sapu (Baeckea } \\
\text { frutescens) }\end{array}$ & - & $0,33 \times 10^{9}$ & $0,33 \times 10^{9}$ & \\
\hline & tiang & $\begin{array}{l}\text { sapu-sapu (Baeckea } \\
\text { frutescens) }\end{array}$ & - & - & - & \\
\hline \multirow{2}{*}{$\begin{array}{l}\text { Hutan } \\
\text { dataran } \\
\text { rendah }\end{array}$} & $\begin{array}{c}\text { semai } \\
\text { pancang }\end{array}$ & $\begin{array}{c}\text { mentangor pret } \\
\text { (Calophyllum sp.) } \\
\text { seruk (Schima wallichii) }\end{array}$ & $\begin{array}{c}3,3 \times 10^{9} \\
-\end{array}$ & $33 \times 10^{-}$ & $\begin{array}{l}3,3 \times 10^{9} \\
33 \times 10^{9}\end{array}$ & \multirow[b]{2}{*}{85,32} \\
\hline & tiang & seruk (Schima wallichii) & $33 \times 10^{9}$ & $16,0 \times 10^{9}$ & $49,02 \times 10^{9}$ & \\
\hline
\end{tabular}

Tinggi rendahnya total populasi bakteri penambat $\mathrm{N}_{2}$ non-simbiotik dipengaruhi oleh ketersediaan sumber energi karbon organik di lingkungan rizosfir [27].

Berdasarkan analisis sifat fisik kimia tanah hutan dataran rendah pejem kedalaman $0-20 \mathrm{~cm}$ memiliki kandungan C-organik lebih tinggi dibandingkan dengan padang sapu-sapu, pada penelitian Nurtjahya et al. [2] C-organik di padang sapu-sapu 0,92\% dan hutan dataran rendah 3,49\%. C-organik yang rendah mempengaruhi total populasi bakteri.

Penelitian Indriani et al. [28] menunjukkan pada percobaan yang menggunakan bahan organik yang mana populasi bakteri penambat $\mathrm{N}_{2}$ non-simbiotik. memiliki populasi tertinggi pada dosis bahan organik 4,5\% dibandingkan dengan populasi dosis bahan organik 1,5\%. Bakteri penambat $\mathrm{N}_{2}$ non-simbiotik menggunakan bahan organik sebagai sumber karbon untuk mendapat energi [13], sehingga populasi bakteri di hutan dataran rendah lebih tinggi dikarenakan bahan organik merupakan makronutrien yang paling utama yang dibutuhkan khususnya karbon dan nitrogen. Madigan et al. [29] menyatakan bahwa bakteri prokariot autotrof mengunakan $\mathrm{CO}_{2}$ sebagai satusatunya sumber karbon sedangkan yang bersifat heterotrof mengunakan molekul organik sebagi sumber pertumbuhannya.
Nitrogen berperan penting dalam metabolisme seluler khususnya dalam pembelahan sel sehingga apabila kandungan nitrogen sedikit maka kemampuan bakteri untuk tumbuh semakin lambat. Berdasarkan analisis fisik kimia tanah pada dua lokasi penelitian kandungan $\mathrm{N}$-total di lokasi hutan dataran rendah 0,21 data pribadi dan di padang sapu-sapu N-total 0,07 [2]. Hal ini menunjukkan bahwa N-total di padang sapusapu lebih rendah dibandingkan dengan hutan dataran rendah dan populasi bakteri di hutan dataran rendah lebih tinggi dibanding di padang sapu-sapu. Nitrogen yang rendah akan mempengaruhi jumlah populasi bakteri sehingga pertumbuhannya menjadi sedikit karena bakteri mengasimilasi senyawa nitrogen organik maupun anorganik untuk pertumbuhannya. Senyawa nitrogen akan direduksi oleh bakteri menjadi ammonia [30].

Kelembaban tanah juga merupakan faktor yang mempengaruhi populasi bakteri penambat $\mathrm{N}_{2}$ nonsimbiotik karena kelembaban tanah menentukan laju penambatan $\mathrm{N}_{2}$ yang mempengaruhi keberadaan bakteri penambat $\mathrm{N}_{2}$ non-simbiotik. Pengukuran mikroklimat pada kedua lokasi penelitian menunjukkan bahwa kelembaban tanah di hutan dataran rendah lebih tinggi yaitu berkisar 68-89 \% dibandingkan dengan hutan padang sapu-sapu yang 
berkisar 41-74,6 \%. Rendahnya kelembaban tanah di hutan padang sapu-sapu disebabkan karena alih fungsi lahan yang terjadi di hutan padang sapu-sapu menjadi tambak udang, pembakaran hutan, penebangan pohon untuk kayu bakar dan bahan bangunan rumah masyarakat sekitar [29].

Kelembaban yang rendah akan menjadikan kondisi aerob sehingga akan mempengaruhi aktivitas enzim nitrogenase yang dimiliki oleh bakteri penambat $\mathrm{N}_{2}$ non-simbiotik menjadi tidak aktif jika tekanan oksigen tinggi. Kelembaban yang tinggi akan menjadikan kondisi anerob sehingga aktivitas enzim nitrogenase menjadi aktif dan menyebabkan populasi bakteri tinggi [31].

Bakteri aerob penambat $\mathrm{N}_{2}$ non-simbiotik membutuhkan oksigen untuk pertumbuhannya namun adanya oksigen akan mempengaruhi enzim nitrogenase. Perlindungan enzim terhadap oksigen yang dilakukan oleh bakteri aerob khususnya bakteri Azotobacter karena memiliki kapsul lendir yang tersusun dari polisakarida menyebabkan bakteri mampu bertahan dalam keadaan anerob [32].

Selain kelembaban dan bahan organik yang mempengaruhi populasi penyebaran bakteri penambat $\mathrm{N}_{2}$ non-simbiotik, temperatur juga merupakan faktor penentu sebaran populasi bakteri tersebut. Temperatur tanah yang tinggi dapat menghambat pertumbuhan bakteri penambat $\mathrm{N}_{2}$ non-simbiotik. Bakteri penambat $\mathrm{N}_{2}$ non-simbiotik tumbuh optimal pada temperatur $30-35^{\circ} \mathrm{C}$ [33]. Temperatur tanah pada penelitian di lokasi hutan dataran rendah berkisar 29$31^{\circ} \mathrm{C}$ dan di lokasi padang sapu-sapu berkisar $30-41{ }^{\circ} \mathrm{C}$. Temperatur tinggi di hutan padang sapu-sapu mempengaruhi populasi bakteri penambat $\mathrm{N}_{2}$ nonsimbiotik, sehingga populasi bakteri di hutan padang sapu-sapu lebih rendah dibandingkan dengan hutan dataran rendah. Pranoto et al. [34] menyatakan bahwa bakteri penambat $\mathrm{N}_{2}$ non-simbiotik khususnya bakteri Azotobacter sensitif terhadap temperatur $35^{\circ} \mathrm{C}$.

\section{KESIMPULAN}

Bakteri penambat $N_{2}$ non-simbiotik (BPN) di padang sapu-sapu dan hutan dataran rendah berjumlah enam isolat, satu diantaranya diduga berpotensi sebagai pupuk hayati. Kelimpahan bakteri penambat $N_{2}$ nonsimbiotik di padang sapu-sapu lebih rendah dibandingkan di hutan dataran rendah. Isolat
TH105(a) dengan genus Azotobacter dari hutan dataran rendah berpotensi digunakan sebagai pupuk hayati.

\section{UCAPAN TERIMA KASIH}

Penulis mengucapkan terima kasih kepada pihak Laboratorium Mikrobiologi Jurusan Biologi. Universitas Bangka Belitung, SEAMEO-BiotropBogor, dan Laboratorium Kesehatan Daerah Bangka Belitung yang memfasilitasi peminjaman alat dan tempat bagi peneliti.

\section{DAFTAR PUSTAKA}

[1] Whitten T, Damanik SJ, Anwar J, Hisyam N. 2000. The Ecology of Sumatera. Singapore: Periplus Editions.

[2] Nurtjahya E, Setiadi D, Guharja E, Muhadiono, Setiadi Y, 2008. 'Succession on Tin Mined Land in Bangka Island".

[3] Patti PS, Kaya E, Silahooy. 2003. Analisis Status Nitrogen Tanah dalam Kaitannya Dengan Serapan N oleh Tanaman Pada Sawah Di Desa Waimital, Kecamatan Kairatu, Kabupaten Serang Bagian Barat. Agrologi. 2(1): 51-58.

[4] Schlegel HG, Schmidt K. 1994. Mikrobiologi Umum. Yogyakarta : UGM.

[5] Miharja OAA. 2018. Peningkatan pertumbuhan dan hasil kedelai serta efisiensi pemupukan fosfat sebagai akibat pemberian pupukhayati pada tanah utisol jatinangor.

[6] Widiyawati I,Sugiyanta, Junaedi A,Widyastuti R. 2014. Peran Bakteri Penambat Nitrogen untuk Menggurangi Dosis Pupuk Nitrogen Anorganik pada Padi Sawah. J. Agron indonesia. 42(2): 96-102.

[7] Setiadi Y. 2009. Revegetasi Lahan Pasca Penambangan Menggunaka Inokulan Bakteri pada Tumbuhan, Bogor. Jurnal Biodiversitas. 6(2): 20-22.

[8] Reyes I, Valery A, Valduz Z. 2006. PhosphateSolubilizing Microorganism Isolated from Rhizopheric and Bulk of Colonizer Plants at an abandoned rock phosphate mine pant and soil. Plant soil. 287(1): 69-75.

[9] Widawati S, Muharam A. 2012. Uji laboratorium Azospirillum sp. yang disiolasi dari bebrapa ekosistem. J.hort. 22(3): 258-267.

[10] Caceres EAR. 1982. Improved medium for isolation of Arospirillum spp. Appl Environ Microbiol. 44(4): 990-991.

[11] Saraswati R, Husen E, Simanungkalit RDM. 2007. Metode Aanalisis Biologi Tanah. Bogor: Balai Besar Penelitian dan Pengembangan Sumber Daya Lahan Pertanian. 
[12] Baldani VLD, Dobereiner J. 1980. Host-Plant Specifity in The Infection of Cereals With Azospirillum spp. Soil Biology and Biochenistry. 12: 433-439.

[13] Holt JG, Krieg NR, Sneath PHA, Staley JT, Williams ST, 1994. Bergey's Manual Determinative Bacteriology 9th. USA: Williams \& Wilkins.

[14] Irianto. 2006. Mikrobiologi: Menguak Dunia Mikroorganisme Jilid 1. Bandung : Yrama Widya.

[15] Sari E. 2015. Eksplorasi Vegetasi Fitoremediator dan Bakteri Rizosfer Resisten Logam Berat Pb dan Sn di Lahan Bekas Tambang Timah Pulau [Tesis]. Bogor: Sekolah Pascasarjana, Institut Pertanian Bogor.

[16] Gordon SA, Weber RP. 1951. Colometric Estimation of Indoleacetic Acid. Plant Physiology. 26: 192-195.

[17] Gibson AH, Turner GL. Meansurement of Nitrogen Fixation by Indirect Means.Di dalam: Bergensen FJ, editor. Methods for .

[18] Remya M, Vijayakumar R. 2008. Isolation and Characteization of Marine Antaginistic Actinomycetes From West Coast of India. Medicine and Biology. 15(1): 13-19.

[19] Arwiyanto T, Astuti A, Maryudani YMS. 2007. Karakteristik Parsial Streptomyces ssp, Agen Pengendali Penyakit Lincat Tembakau. 2:95-105

[20] Rusmana I, Hadijaya DD. 1994. Aktivitas nitrogenase Azospirillum sp. dan Efektivitas dengan Jagung. J.Hayati. 1:51-54.

[21] Astuti FF, Habazar T, Nasution CR, Yanti Y. 2017. Sreening of Rhizobacteria from Rhizosfhere of Healthy Chili to Control Bacterial with Disease and Promote Growth and Yield of Chili. J biodiversitas. 18 (1):1-9.

[22] Alexander M. 1997. Introduction to Soil microbiology. John Wiley \& Son : New York.

[23] Isminarni F, Wedhastri S, Widada J, Purwanto BH. 2007. Penambat Nitrogen dan Penghasil Indol Asam Asetat oleh Isolat-Isolat Azotobacter pada $\mathrm{pH}$ Rendah dan Alluminium Tinggi. Jurnal Ilmu Tanah dan Lingkungan. 7(1): 23-30.

[24] Kaburuan R, Hapsoh, Gusmawaratai. 2014. Isolasi dan Karakterisasi Bakteri Penambat Nitrogen NONSimbiotik Tanah Gambut Cagar Biosfer Giam Siak Kecil-Bukit Batu. Jurnal Agroteknologi. 5(1): 35 - 39.

[25] Gholami A, Shahsavani S, Nezarat S. 2009. The Effect of Plant Growt and Yield of Maize. World Academy of Science, Engineering And Technology. 49: 19-24.

[26] Firrani M. 2011. Isolasi dan Uji Kemampuan Bakteri Endofit Diazotrof yang Memfiksasi Nitrogen Bebas pada Akar Kelapa Sawit (Elaeis guineensis Jaqc.). [Skripsi]. Universitas Sumatera Utara.

[27] Simanungkalit. 2006. Pupuk Organik dan Pupuk Hayati. Bogor: Balai Besar Penelitian dan Pengembangan Sumber Daya Lahan Pertanian.
[28] Indriani FN, Hindersah R, Suryatmana P. 2017. NTotal, Serapan N dan Pertumbuhan Kacang Tanah (Arachis bypogaea L.) Akibat Inokulasi Azotobacter dan Bahan Organik pada Tailing Tambang Emas Pulau Buru, Maluku. J. Soilrens. 15(2): 33-39.

[29] Madigan MT, Martinko JM, Parker J. 2000. Biologyof Microorganisme. Ed ke-9. New jersey : Pretince hall.

[30] Purwanto BH. 2007. Recovery Rates of Nitrogen Filtilizer Applied of Peat Soils in Different Characteristics and Landuse. J. Ilmu tanah dan lingkungan. 7(2): 117-121.

[31] Wulantika. 2018. Kelimpahan Dan Keanekaragam Cendawan Pelarut Fosfat Padang Sapu-Sapu Pejem Bangka. [Skripsi]. Balunijuk.

[32] Danapriatna N. 2010. Biokimia Penambat Nitrogen oleh Bakteri Non-simbiotik. J.Agribisnis. 1(2): 1-10.

[33] Sethi SK, Adhikary. Azotobacter Plant GrowtPromoting Rhizobacteria Used as Biofertilizer. Dynamic Biochemestry, Proses

[34] Pranoto Y, Salokhe VM, Rakshit SK. 2005. Physical and Antibacterial Properties of Alginate-based Edible Film Incorporated with Garlic Oil. J. Food Res. Intl. 38: 267-272. 